\title{
An integrated approach for carbonate reservoir characterization: a case study from the Linguado Field, Campos Basin
}

\author{
Wagner Moreira Lupinacci ${ }^{1,2 *}\left(\mathbb{D}\right.$, Livia de Moura Spagnuolo Gomes ${ }^{1} \mathbb{D}$, Danilo Jotta Ariza Ferreira ${ }^{1,3}(\mathbb{D}$, \\ Rodrigo Bijani' ${ }^{1}$, Antonio Fernando Menezes Freire' (1)
}

\begin{abstract}
The main reservoirs in the Linguado Field are grainstone and packstone carbonates composed of oolites, oncolites, pelloids, and rare bioclasts, of the Quissamã Formation (Albian-age) and coquinas of the Coqueiros Formation (Aptian-age). Within Quissamã Formation, facies have high porosity variations and their $3 \mathrm{D}$ characterization is of utter importance to allow for a better location of the wells. The objective of this study was a volumetric characterization of Quissamã Formation by means of an adapted classical workflow composed of well-seismic tie, seismic preconditioning, seismic interpretation, seismic inversion, petrophysical properties estimation, and porosity geostatistical modeling. Seismic inversion results allowed the interpretation of a horizon to separate the carbonate platform in an upper zone, with low acoustic impedance, from a lower zone, with high acoustic impedance. Finally, behavioral knowledge of acoustic impedance and the porosity distribution within the Albian carbonate platform helped to better characterize the distribution of carbonaceous facies allowing the confirmation that commercial wells were drilled in low acoustic impedance and high porosity regions. It was also possible to confirm that a well, declared as noncommercial, was drilled in a poor reservoir region with high acoustic impedance and low porosity and identified other locations that were not yet drilled but could represent potential targets.
\end{abstract}

KEYWORDS: reservoir characterization; seismic inversion; porosity modeling.

\section{INTRODUCTION}

The Campos Basin is in the southeastern portion of the Brazilian continental margin. It is limited by two structural highs, to the south by the Cabo Frio High, separating it from the Santos Basin, and to the north by the Vitória High, separating it from the Espírito Santo Basin (Fig. 1). Its origin is related to the breakup of the Gondwana supercontinent, which separated the South American and African tectonic plates, with the consequent origin of the Atlantic Ocean, around $130 \mathrm{Ma}$, culminating in the formation of the Brazilian and African marginal basins (Bueno 2004). Tectono-stratigraphy evolution of the Campos Basin (Fig. 2) can be divided into three super sequences: rift, post-rift, and drift (Winter et al. 2007).

The Quissamã Fm. was deposited during the Early to the Middle Albian age, during drift phase and represents the first sediments of marine environment, in a context of carbonaceous

${ }^{1}$ Grupo de Interpretação Exploratória e Caracterização de Reservatórios, Department of Geology and Geophysics, Universidade Federal Fluminense - Niterói (RJ), Brazil. E-mails: wagnerlupinacci@id.uff.br, liviaspag@gmail.com, danilo.j.ariza@gmail.com, rodrigobijani@id.uff.br, fernando_freire@id.uff.br

${ }^{2}$ Biomass and Water Management Research, UFF - Niterói (RJ), Brazil.

${ }^{3}$ Schlumberger - Rio de Janeiro (RJ), Brazil.

${ }^{*}$ Corresponding author. ramp along the NE-SW direction, with an average thickness of $800 \mathrm{~m}$ (Dias-Brito 1987, Guardado et al. 1989, Okubo et al. 2015). This Formation has as lower limit the evaporites of the Retiro Fm., and as upper limit a maximum flooding surface, denominated Marco Beta (Guardado et al. 1989). Halokinesis played an important role in the sedimentary deposition of this sequence since it acted as a structural control through faulting and, consequently, reservoir compartmentalization (Spadini and Paumer 1983, Spadini et al. 1988).

The Quissamã Fm. can be further sub-divided into two sequences: basal and upper. The basal sequence was deposited

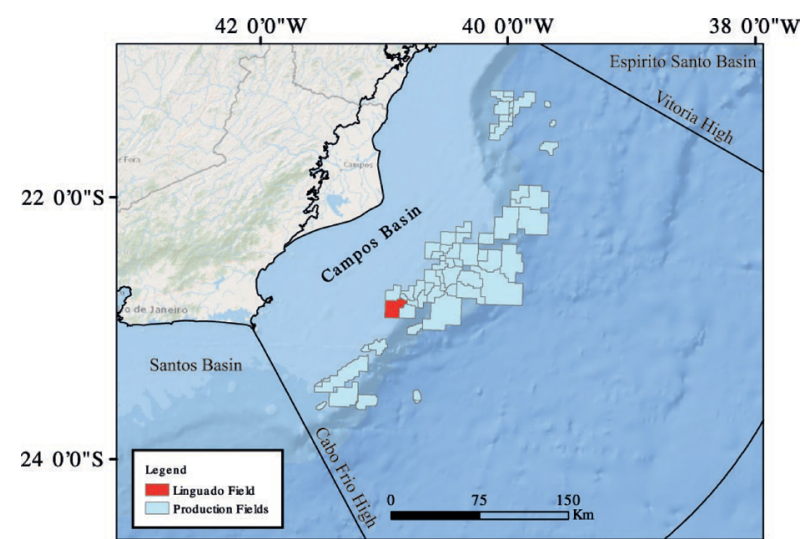

Figure 1. Localization of the Linguado Field (in red), Campos Basin, Brazil. 
in a tidal lagoon system environment in restricted marine settings and consists of different dolomites protoliths, being, predominantly, mudstones and, more rarely, grainstones (Okubo et al.2015). This process of dolomitization decreases progressively toward the top of the sequence and is considered a product of early carbonate diagenesis. According to Azevedo et al. (1987) and Marçal (1993), the diagenetic and dolomitization features of the carbonate rocks may have occurred due to the syn-deposition inflow of meteoric water.

As for the upper sequence, it was deposited in a carbonate bank system, originated by a series of shallowing-upward cycles which usually begin with the deposition of oncolytic and peloidal mudstones and packstones, culminating in oolitic and oncolytic grainstones and packstones, considered the high-energy facies (Esteves et al. 1987, Spadini et al. 1988, Winter et al. 2007). This facies association was also confirmed by Okubo et al. (2015) and Favoreto et al. (2016) who, by using sidewall samples, cuttings and thin sections of the Quissamã Fm., described associations of facies delimited by their distributions in the carbonate platform environment. Carbonate bank facies were represented by deposition of oolitic/oncolytic grainstones in a high-energy environment, interbank facies are characterized by the predominance of bioclastic/peloidal packstones and wackestones deposition in a lower energy environment. These authors also identified post-depositional features confirming the action of diagenetic processes, such as, micritization, cementation, dissolution, compaction, dolomitization, and re-crystallization, mainly in the lower part of the formation.

Fernandes et al. (2017) obtained pseudo-porosity and density maps on the top of the Quissamã Fm in Linguado Field through the use of seismic attributes coupled with well $\log$ evaluation. They observed great porosity variation in the main structural high, despite the well logs indicating average porosities of $20 \%$ for the Albian carbonate reservoirs. The significant porosity variation along the field is due to the great lateral heterogeneity of the carbonate rocks.

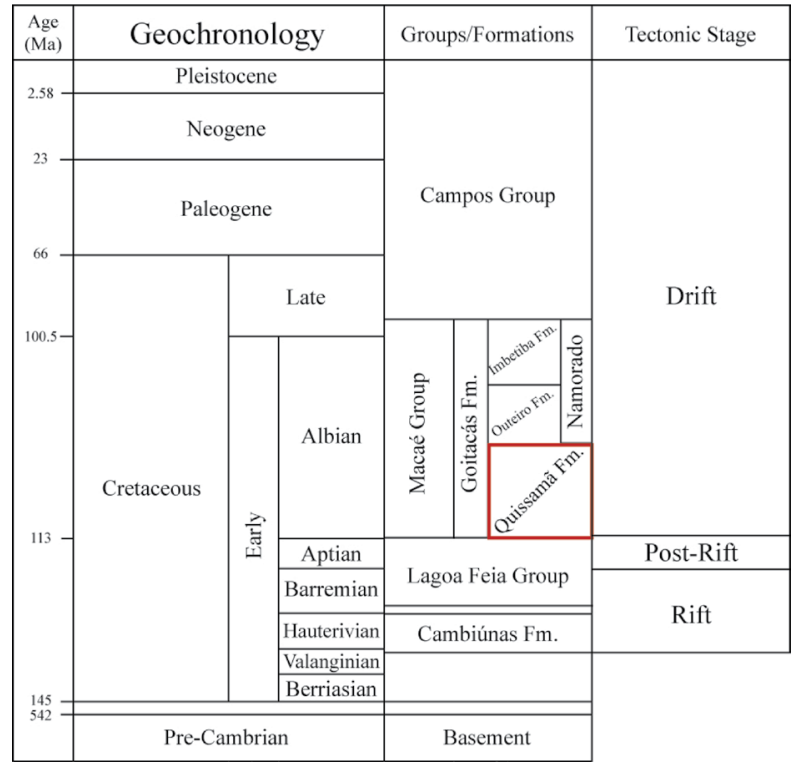

Source: adapted from Winter et al. 2007).

Figure 2. Tectono-stratigraphic chart of Campos Basin
Therefore, the present study is focused on the 3D characterization of Albian carbonate reservoirs of the Quissamã Formation (Fm.) in the Linguado Field, located in the Campos Basin (Fig. 1), to better understand its variation in the terms of reservoirs facies and property distribution. Our proposed methodology is an adapted classical workflow through acoustic inversion and geostatistical porosity modeling since the Albian carbonate platform has a high intercalation of carbonate facies and shales, which makes difficult to characterize it only based on the amplitude seismic data. Finally, a quantitative analysis of the results with the integration of well log evaluation, structural interpretation, seismic inversion, and porosity volume was carried out.

\section{METHODOLOGY}

The data used in this research were post-stack time-migrated $3 \mathrm{D}$ seismic data, covering an area of $80 \mathrm{~km}^{2}$, and nine well logs of the Linguado Field. The location of seismic volume, the wells, and the four seismic lines (three inlines and an arbitrary line trace, which will be discussed later) are shown in Figure 3.

The first step comprised the interpretation of the main seismic-stratigraphic sequences as well as the economic basement and the sea floor. These sequences were defined based on the identification of discontinuities, and from reflection termination patterns, such as onlap, down lap and top lap, allowing the discrimination of stratigraphic intervals. Well marker information after initial well-tie was used to establish the age of these intervals. The section of interest was the carbonate platform deposited between the end of the Aptian and the Middle of the Albian (Quissamã Fm.). Therefore, the seismic horizons that correspond to these ages represent, respectively, the platform's top and bottom surfaces. Also, the main faults that cross this stratigraphic section were interpreted and through the integration of faults, horizons, and well tops data, a structural model and grid was created and used for porosity modeling.

Seismic data preconditioning was applied to increase the seismic resolution and to remove random and coherent noise, allowing the acoustic impedance results to provide a more realistic geological model with higher resolution. Curvelet-domain and inverse $Q$ filtering were used, based on the work of Lupinacci et al. (2017). Curvelet filtering consists of a multispectral tool for removal of random and coherent noise at different scales (frequencies) and orientations (Candès et al.2006). As for the inverse $Q$ filtering, it compensates the effects of earth attenuation that causes loss of high frequencies in seismic data, thus increasing seismic resolution. The inverse $Q$ filtering developed by Braga and Moraes (2013) was used in this study, performing a time-frequency domain filtering based on the continuous wavelet transform and allowing to limit the exponential gain for each frequency component, thus decreasing the addition of high frequency noise.

A well-seismic re-tie was performed focused in the interval of the Quissamã Fm., after seismic data preconditioning aiming to increase correlation. This process is of extreme importance for the seismic inversion, because the higher the 
correlation between the synthetic and original seismic traces, the greater the reliability in the obtained acoustic impedance model (Jarvis 2006).

The initial acoustic impedance model aims to add the low frequencies absent in the seismic data to the inversion process and was constructed from the interpolation of the well log acoustic impedance trends, using the distance inverse square (Franke 1982). The wavelet used in the inversion was the average of the estimated wavelets in the well-seismic re-ties process with correlation values greater than $60 \%$.

Model-based inversion (Russell and Hampson 1991, 2006) was used, in which, for the case of acoustic inversion, an initial acoustic impedance model and a seismic wavelet were required. A synthetic seismic trace for each acoustic impedance profile of the initial model is calculated. Then, the acoustic impedance values are gradually modified until the synthetic seismic trace approaches the original seismic trace, i.e., within the acceptable limits set by the user. The model-based inversion is widely used, and several recent articles have been published for characterization of carbonate reservoirs (Jalalalhosseini et al.2015, Al-Rahim and Hashem 2016, Pramudito et al. 2017, Ferreira and Lupinacci 2018), as well as for siliciclastic ones (Maurya and Singh 2015, Karin et al. 2016).

The variation limits of the acoustic impedance values were restricted by the hard-constrained method which consists of limiting the maximum and minimum values based on the welllog acoustic impedance. The variation limits chosen were $50 \%$. The inversion was performed in the interval between 1,300 and 2,300 ms and the well 4-RJS-0156-RJ was used as quality control for the inversion process; thus, it was not used in building the model nor as a constraint on the inversion process.

In the resulting acoustic impedance model, it was possible to map a horizon, named as Q1 horizon (or the intra-Albian horizon). This horizon separates the carbonate platform into two sections and is not a seismic horizon, since it was not possible to map it from the seismic amplitude. Next, porosity modeling was performed using the porosity well logs as primary variable and the acoustic impedance volume as secondary variable. The high negative correlation coefficient between these two properties at the well locations within Quissamã Fm. is shown in Figure 4. This study used the sequential Gaussian simulation method with colocalized co-kriging (Yamamoto

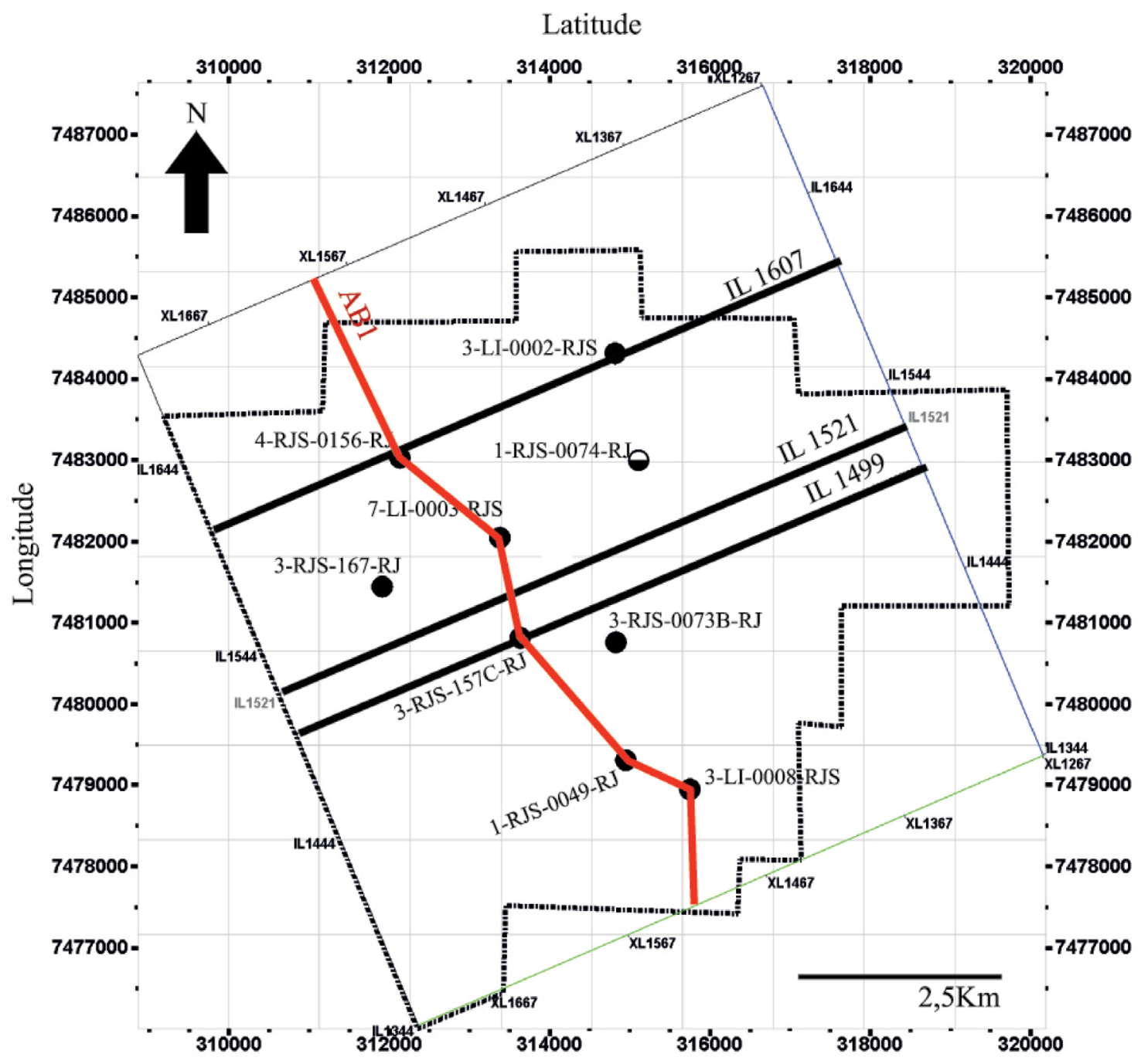

Figure 3. Data used in this study. The seismic cube survey is represented by the polygon, the wells are represented by circles, and colored lines IL1499, IL 1521, IL 1607, and AB1 represent inlines 1499, 1521, and 1607 and an arbitrary line trace, respectively. Linguado Field study area is shown by the dashed line. 
and Landim 2013, Azevedo and Soares 2017). The Gaussian sequential simulation is based on the kriging method for the generation of realizations, using multivariate Gaussian functions. It aims to reproduce properties of the sample set through the sequential use of conditional distributions, which represent functions that completely describe the probability distribution of a random variable (Caers 2000). The colocalized co-kriging represents the inclusion of secondary variables, much more sampled in the study area than the primary ones, through their high correlation with one another. Co-kriging has the objective of accounting for lacking primary data within the modeled area (Yamamoto and Landim 2013). Porosity logs (primary variable) were calculated from the neutron and density logs and then transformed into the normal distribution Gaussian space, and together with the semi-variograms constructed from those well logs simulation was performed. The workflow used is shown in Figure 5.

\section{RESULTS AND DISCUSSION}

In some seismic sections, for a better understanding of the study area, the following horizons were interpreted: top of the basement, base of the Quissamã Fm. (Late Aptian), top of the Quissamã Fm. (Early Albian), top of the Outeiro Fm.

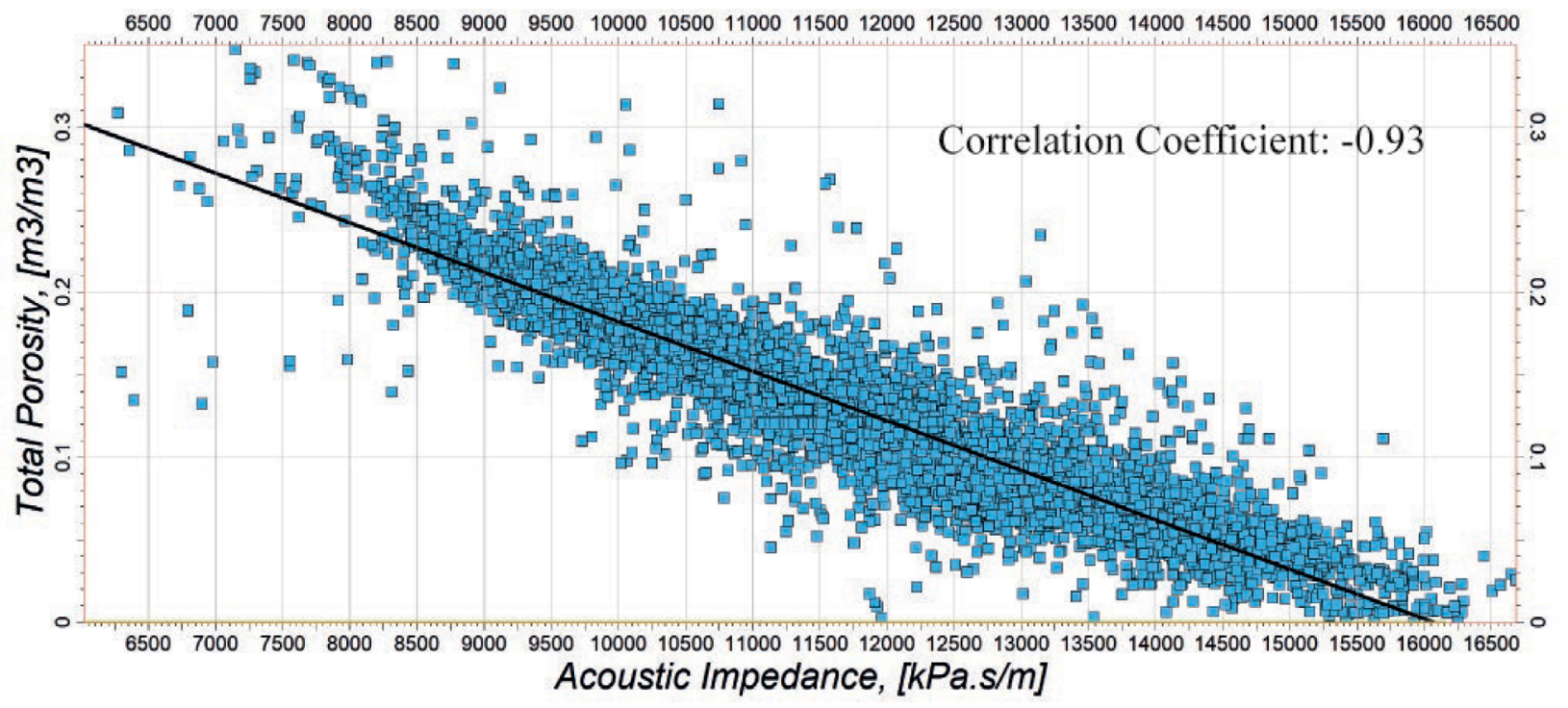

Figure 4. Crossplot between acoustic impedance and porosity logs in the Quissamã Fm. interval. Correlation coefficient is -93\%, indicating high negative correlation.

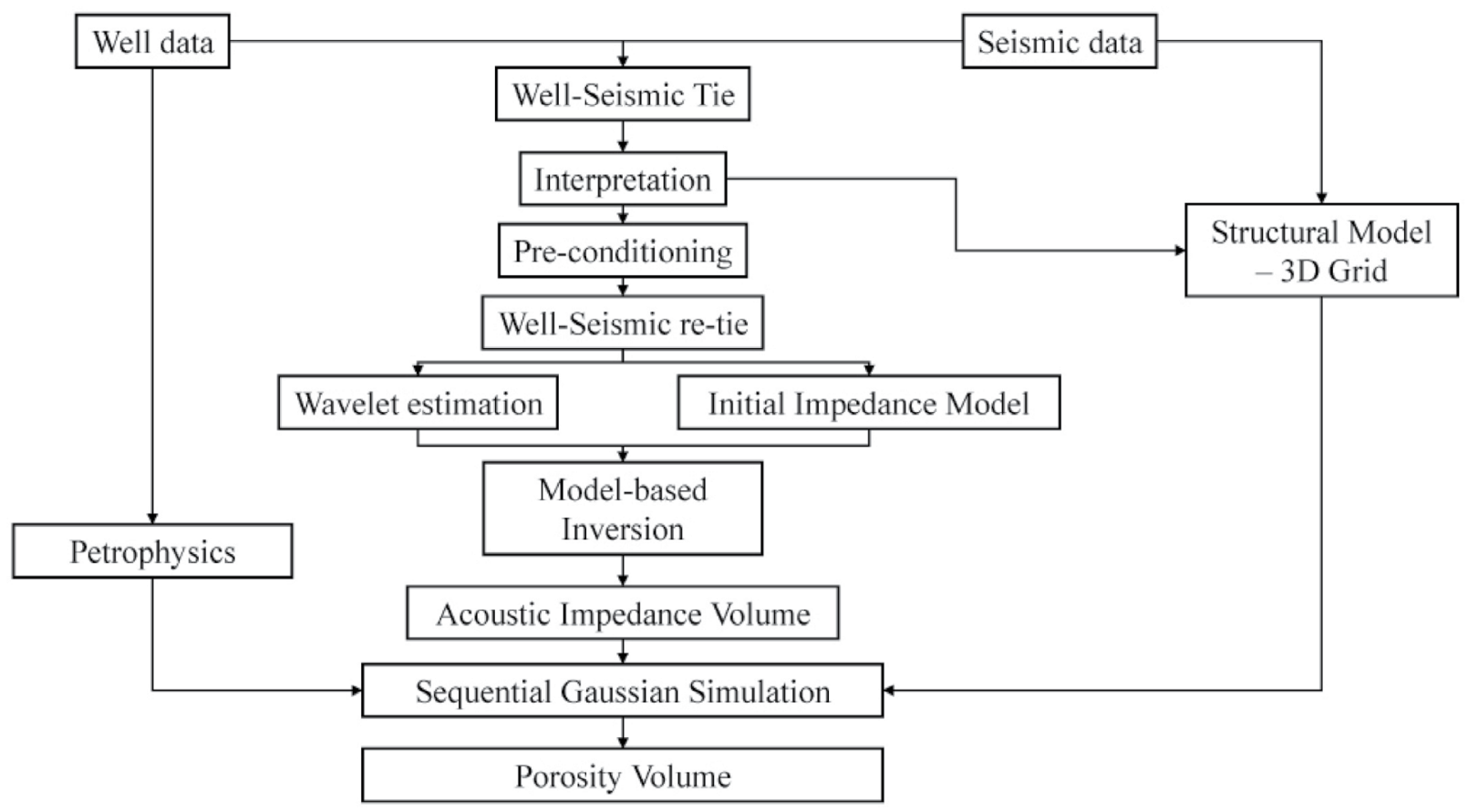

Figure 5. Workflow used to characterize the Albian carbonate reservoirs of the Linguado Field. 
(Late Albian), and the sequences between the Maastrichtian to the seabed comprising the Carapebus, Ubatuba, and Emborê Formations. The rift and post-rift sequences of the basin are represented by the Lagoa Feia Group (from basement to the base of the Quissamã Formation) and the drift sequence is represented from the base of the Quissamã Fm. to the seabed (Winter et al.2007). Figure 6 shows these horizons in inline 1521.

As the focus of this study were the carbonates of the Quissamã Fm., the base and the top of this formation were mapped throughout the whole seismic volume, and then the interpolated time maps of these two horizons were generated. In the Linguado Field, the Quissamã Fm. is formed by facies deposited in structural highs in a carbonate platform of preferential NE-SW direction, where higher-energy facies occur in the central part and the moderate energy ones in the flanks (Okubo et al. 2015).

Figure 7 shows two-way time to the top of the Quissamã Fm. surface and the wells in the study area and it is possible to observe an increasing trend of two-way time from west to east, due mainly to the characteristic morphology of the carbonate platform, which presents itself as a homoclinal ramp with slope to E-SE. It is also noted that the wells were preferably drilled in high structural regions, except for wells 3-LI-0002-RJS, 1-RJS0074-RJ, and 3-LI-0008-RJS. Well 3-LI-0002-RJS, unlike the others, is in a fault border region. Then, the interpretation of the main faults of the beginning of the drift phase was performed, in which most have ENE-WSW direction and some NNE-SSW direction. The structural model was generated between the base

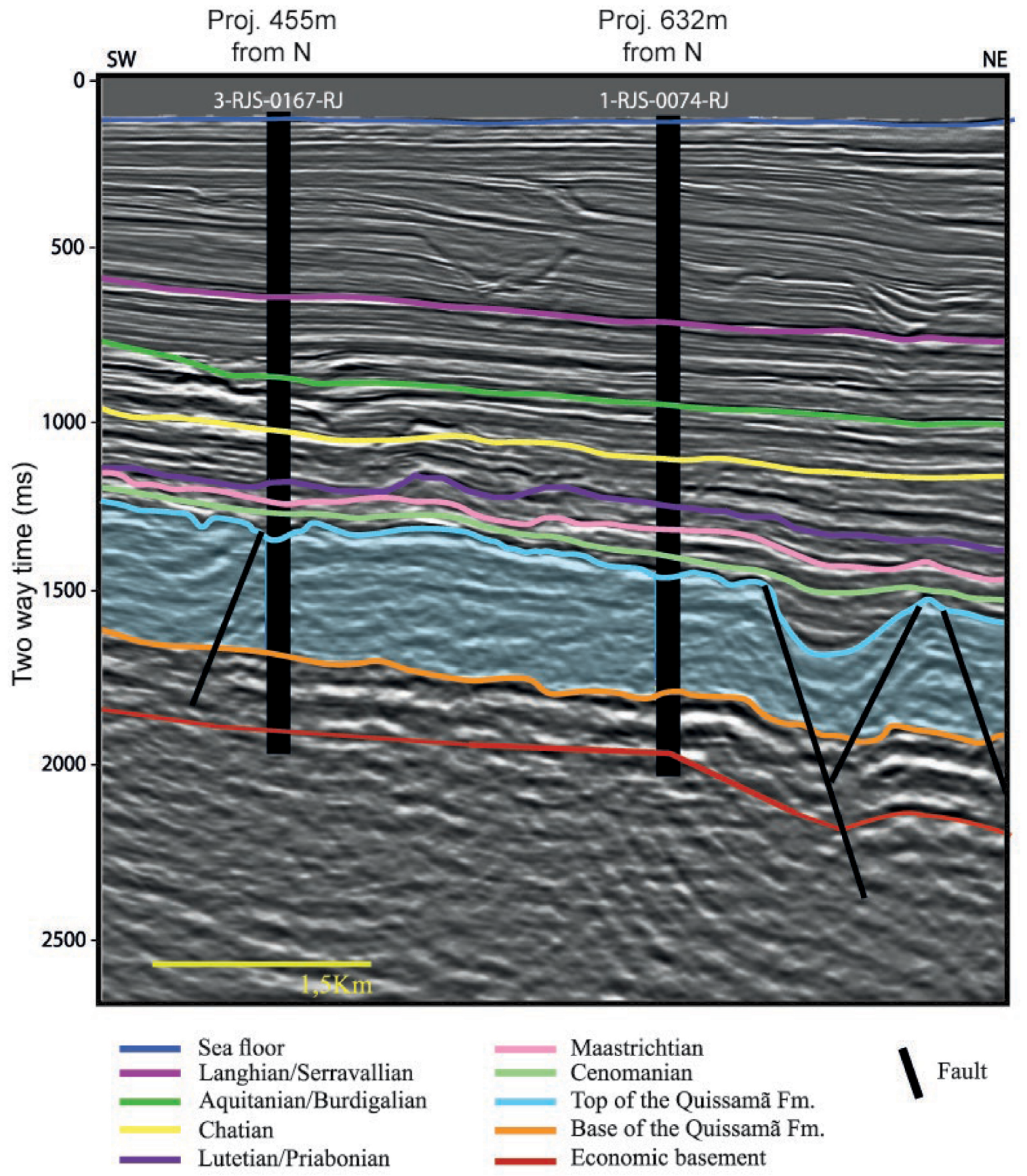

Figure 6. Interpreted seismic-stratigraphic sequences and major faults of inline 1521. 
and the top of the Quissamã Fm. horizons and the main faults in this interval (Fig. 8). Between these two horizons, Q1 horizon was included in the structural model in the gridding stage for porosity modeling to create two main zones that were later equally layered into 20 intervals with $17 \mathrm{~ms}$ time average thickness.

The acoustic impedances from well logs, the ones used in the initial model and the ones resulting from seismic inversion are both shown in Figure 9 for quality control and show good fit between the measured and estimated values.

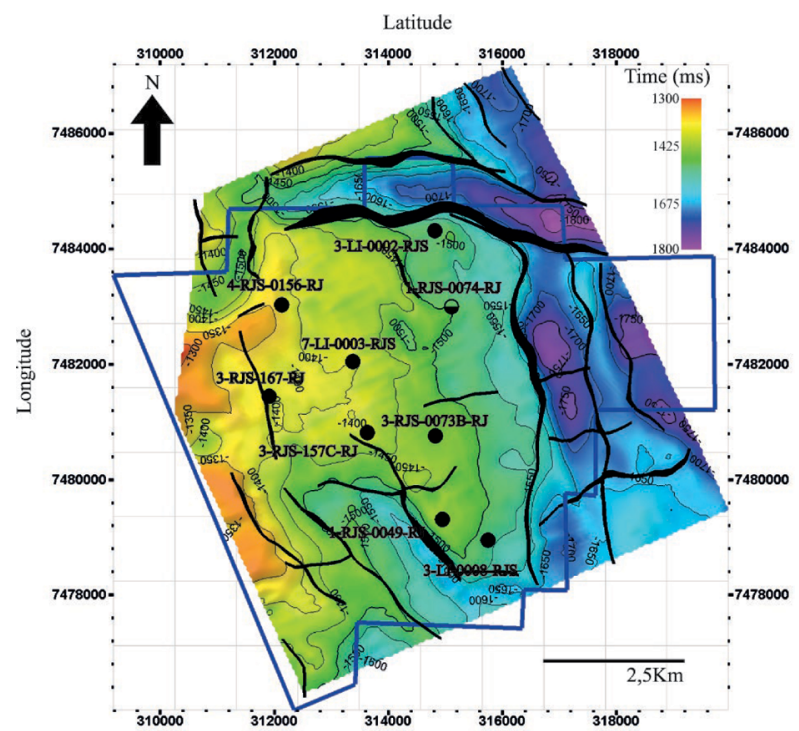

Figure 7. Map of the top of the Quissamã Fm. Black circles represent the well positions. Linguado Field study area is shown by the dark blue line. a)

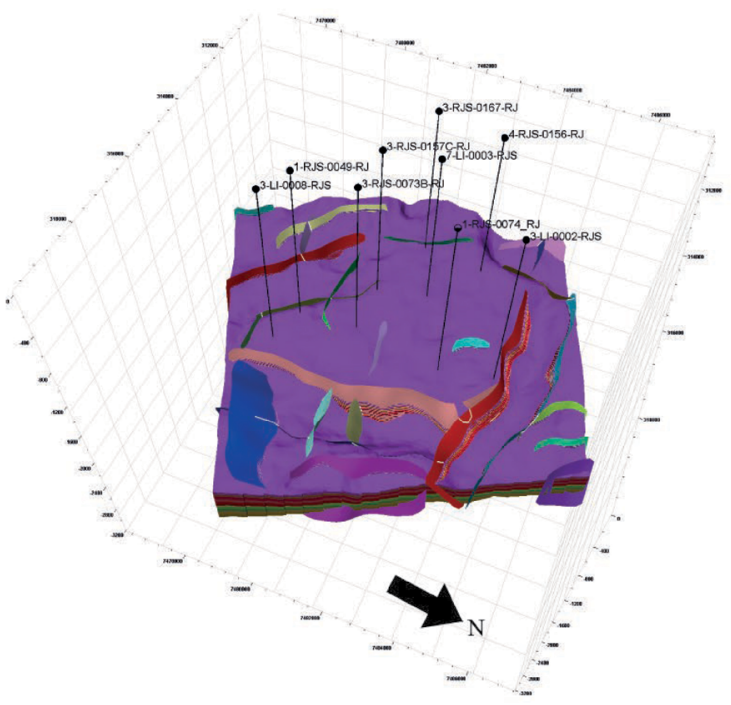

b)

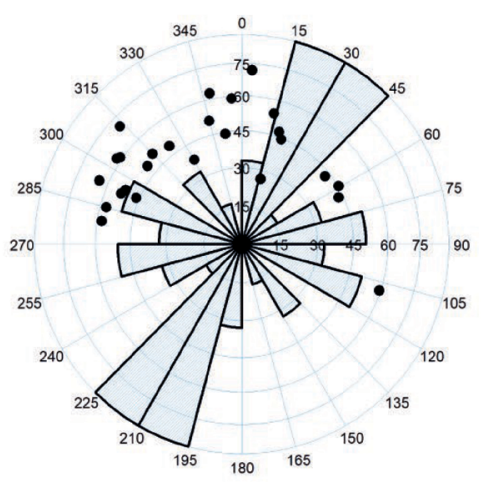

Figure 8. Structural model and main faults mapped in (A) the study area and (B) stereo net view of fault planes.

1-RJS-0049-RJ 1-RJS-0074-RJ 3-LI-0002-RJS 3-LI-0008-RJS 3-RJS-0073B-RJ 3-RJS-0157C-RJ 3-RJS-0167-RJ 7-LI-0003-RJS

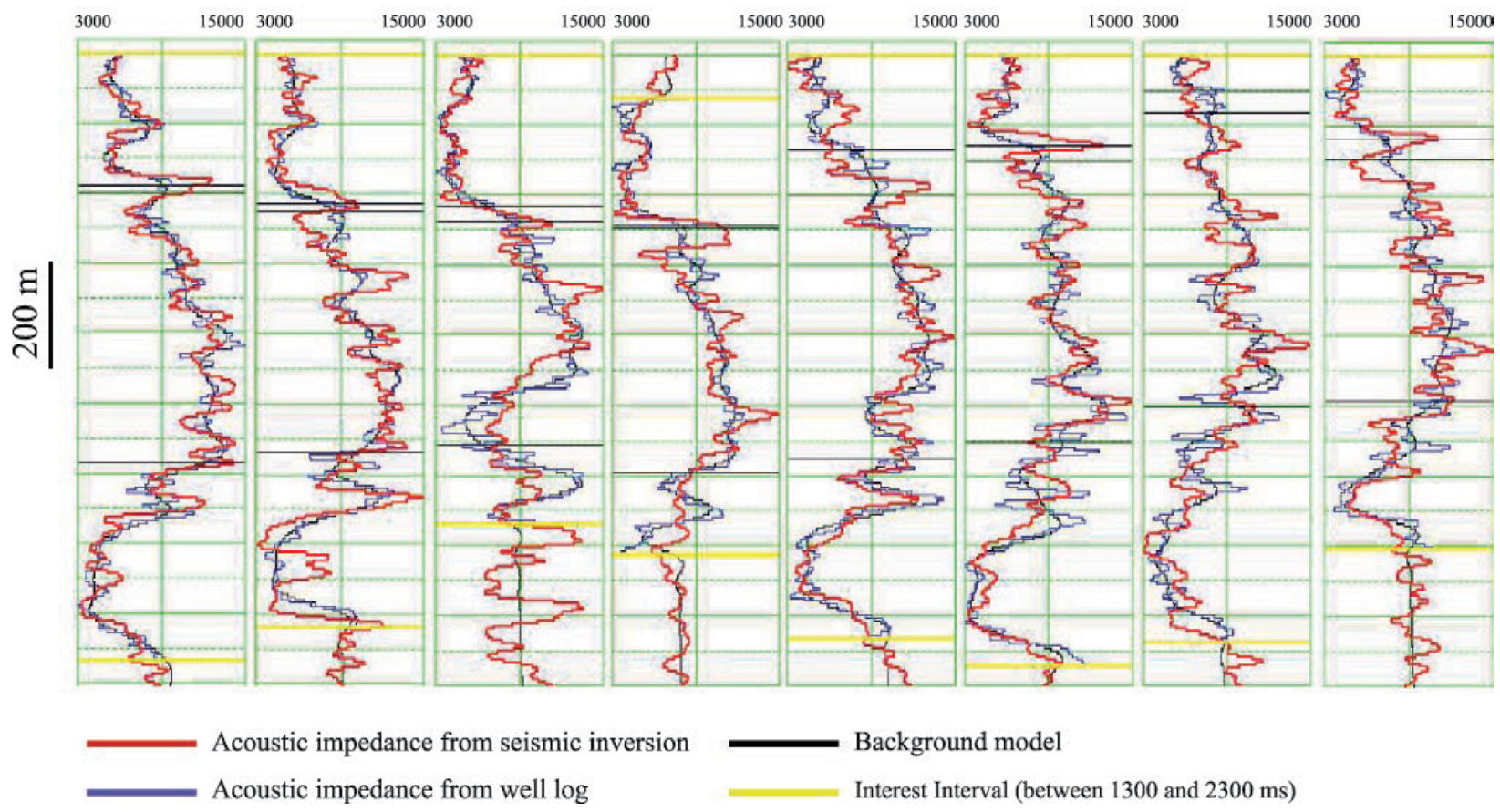

Figure 9. Comparison between the acoustic impedance log (blue curve), the acoustic impedance from the seismic inversion (red curve), and the background acoustic impedance model (black curve) at wells location for quality control of the seismic inversion. 
The acoustic impedance results are shown in the inline 1499 and in an arbitrary line in Figures 10A and 10B, respectively. It is worth mentioning that well 4-RJS-0156-RJ, in Figure 10B, was used in the seismic inversion as quality control, and it presented an excellent correlation between the original acoustic impedance well log and the ones extracted from the resulting inversion volume, corroborating the reliability of the results obtained in the seismic inversion. With the result of the seismic inversion, it was possible to observe a separation between the basal part, presenting high values of acoustic impedance, and the top of the sequence, presenting low values of acoustic impedance. This allowed the mapping of a surface, named

a)

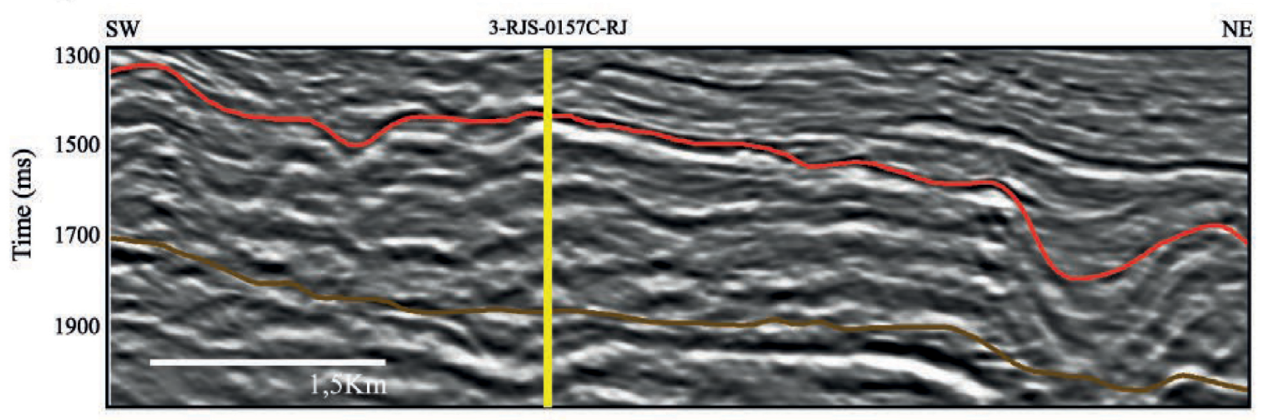

b)

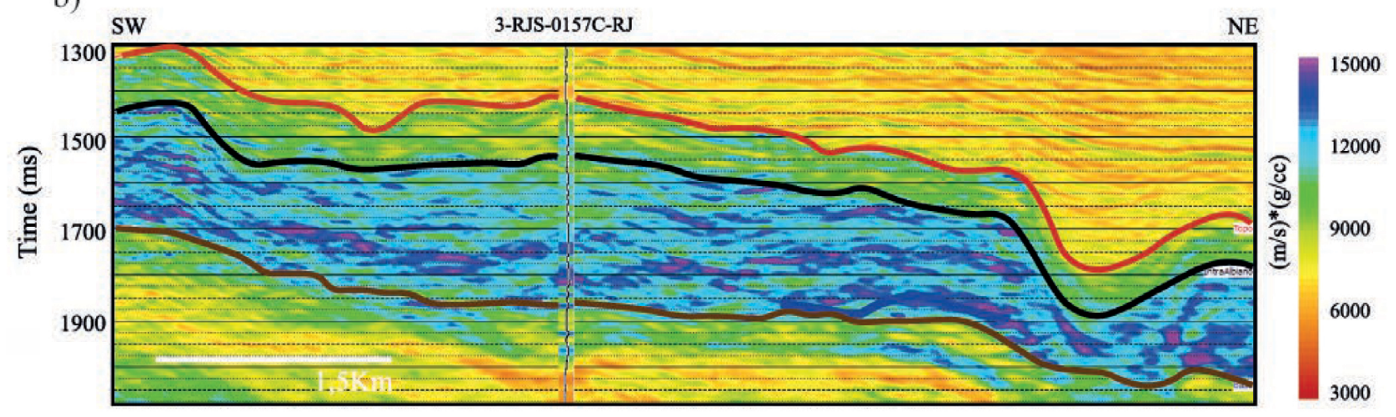

c)

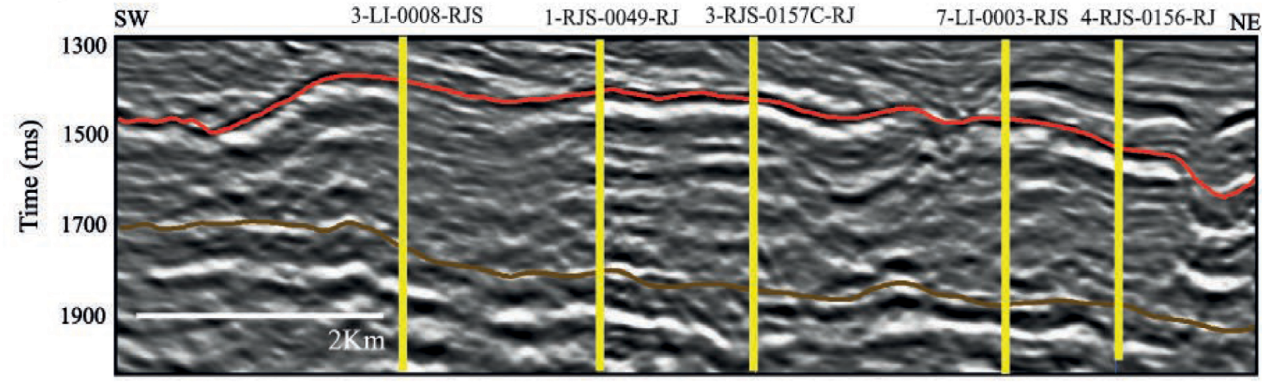

d)

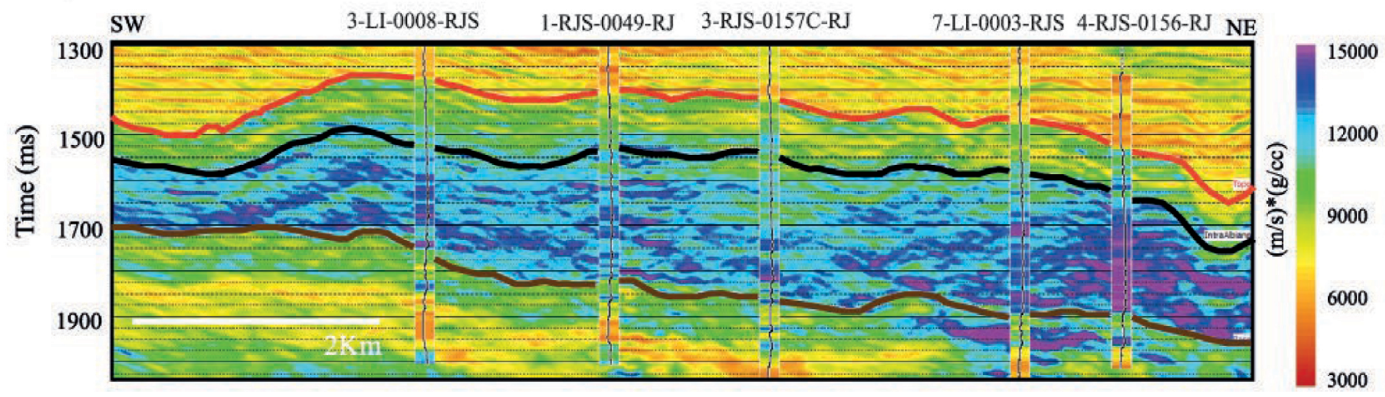

Top of the Quissamã Fm.
Q1
Base of the Quissamã Fm

Figure 10. Amplitude seismic data in (A) and (C) and acoustic impedance in (B) and (D) for the 1499 and AB1 sections, respectively. The base of the Quissamã Fm., the intra-Albian (Q1) and the top of the Quissamã Fm. are represented by brown, black, and red lines, respectively. The acoustic impedance logs of wells 3-RJS-0157-RJ, 3-LI-0008-RJS, 1-TJS-0049-RJ, 3-RJS-0157C-RJ, 7-LI-0003-RJS, and 4-RJS-0156-RJ are also shown. 
as Q1 surface separating an upper sequence with low acoustic impedance (values less than $11,000 \mathrm{~m} / \mathrm{s}^{*} \mathrm{~kg} / \mathrm{m}^{3}$ ) from a basal sequence with high acoustic impedance (with values greater than $11,000 \mathrm{~m} / \mathrm{s}^{*} \mathrm{~kg} / \mathrm{m}^{3}$ ).

Based on the works by Esteves et al. (1987), Spadini et al. (1988), Guardado et al. (1989), Winter et al. (2007), and Okubo et al. (2015), and side-wall samples and evaluation of well logs, it is possible to infer that the carbonate facies in the structural highs, between the Q1 and top of the Quissamã Fm. surfaces, are predominantly composed of an intercalation of packstones and grainstones. These are high energy facies, related to active bars, which represent oolitic and oncolytic banks distributed in the central part, with NE-SW direction based on the bibliographic review. The facies between Q1 and base of the Quissamã Fm. surfaces are predominantly composed of dolomitized and cemented packstones, wackstones, and mudstones. In some regions, the basal part consists of anhydrite, marking the transition from the Lagoa Feia group. The carbonate facies in the basal part are of low energy and were deposited in carbonate platform flanks.

The instantaneous acoustic impedance on the top of the Quissamã Fm. surface is shown in Figure 11. It is possible to observe that, for the most part, the wells were drilled in the regions with low acoustic impedance values. Also, in some regions near the fault edges, low acoustic impedance values occur, which may be associated with a collapse of the carbonate platform and resulting in slumping/sliding facies. However, wells 1-RJS-0074-RJ and 3-RJS-0167-RJ were drilled in regions with high acoustic impedance values.

Maps were obtained applying shifts of $-12,-24,-36$, and $-48 \mathrm{~ms}$ in relation the top of the Quissamã Fm. surface, to analyze the instantaneous acoustic impedance values in the upper part of the Albian carbonate platform (Fig. 12). An increase in acoustic impedance values is observed near all the wells as

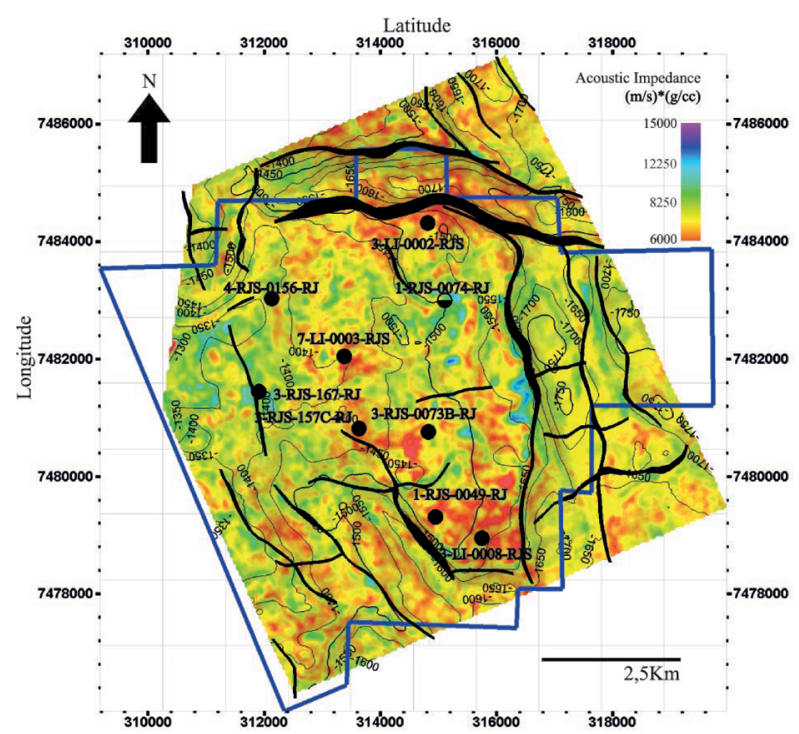

Figure 11. Acoustic impedance attribute map for the top of the Quissamã Fm. surface. Black circles represent the wells and black planes represent mapped faults. Linguado Field study area is shown by the dark blue line. the shifting down of the surface increases indicating that reservoir quality decreases toward the base. However, this increase is even more pronounced in the region of well 1-RJS-0074-RJ. No significant increase in acoustic impedance values is observed around well 3-RJS-0167-RJ with the increase of the shift, which could represent consistent reservoir facies. Also, well 3-LI-0002-RJS, which is in a failure edge, presents relatively low acoustic impedance values with the increase of the shift.

Figure 13 shows the porosity logs and the modeled porosities of wells for quality control and their excellent correlation. The upper section of most wells present porosities greater than the lower section of the Quissamã Fm. This is associated with the lower section being quite dolomitized and cemented. The porosity modeling results using the sequential Gaussian simulation with colocalized co-kriging, having as secondary variable the acoustic impedance volume, was performed in the Quissamã Fm. and is shown in Figure 14. From the porosity modeling, it was possible to observe an area with lower average porosity of $12 \%$ at the basal portion of the platform, between base of the Quissamã Fm. and the Q1 surface, and an area with greater average porosity of $18 \%$ at the upper portion, between the $\mathrm{Q} 1$ and the top of the Quissamã Fm. surfaces, corroborating the seismic inversion. Some of these areas with greater porosity coincide with some wells that presented good net-to-pay in the evaluation of well logs. It is noteworthy that the 3-LI-0002-RJS well was drilled in an area of high porosity, while well 4-RJS-0156-RJ presents high porosity only in a thin layer, close to the $\mathrm{Q} 1$ surface.

The porosity map on the top of the Quissamã Fm. surface is shown in Figure 15. Well 3-LI-0002-RJS, classified as an oil producer, is in a region with high porosity values, as observed in the section in Figure 15. Well 1-RJS-0074-RJ, classified as a poor-producer, is in a region with very low porosity values, around 6\%. In Figure 15, it is also possible to observe several areas in structural highs with high porosities that have not yet been drilled and may represent new targets in the field. The highest porosity values are located mainly in intervals between the Q1 and the top of the Quissamã Fm. surfaces in debris areas. Wells 3-LI-0002-RJS, 4-RJS-0139-RJ, and 1-RJS-0049-RJ are in high porosity structural high regions.

Finally, Figure 16 shows the porosity values in the arbitrary lines $\mathrm{AB} 1$ and Figure 17 in a $3 \mathrm{D}$ view. As it can be observed in Figure 16, most wells were drilled in regions of high to moderate porosity - in other words, good quality reservoirs - at the top of the Quissamã Fm., which contributes to their being good producing wells. In Figure 16, it is observed that the semi-commercial well 1-RJS-0074-RJ was drilled in a region of lower porosities in the upper part of the Quissamã Fm., when compared to other wells. In addition, the thickness of the layer between the $\mathrm{Q} 1$ and the top of the Quissamã Fm. surfaces is thinner at its location.

\section{CONCLUSIONS}

The adapted classical workflow applied to obtain an acoustic impedance volume and porosity model of the Albian carbonate platform in the Linguado Field generated robust results allowing better understanding of its complex reservoir properties distribution. The carbonate platform in the study area is a 
homoclinal ramp platform with slope to ESE. Most of the wells were drilled in structural highs regions, except for three of them, one of which (3-LI-0002-RJ) drilled in a region close to the fault edge. In relation to the structural configuration of the Linguado Field, it is observed that most of the interpreted faults are in the ENE-WSW direction and a few in the NNE-SSW direction. The result of the seismic inversion allowed the mapping of a horizon in the Albian carbonate platform, named Q1 horizon, which separates facies with high impedance values in the basal part from facies with low impedance values in the upper part of the platform. The facies in the upper part have good porosity conditions and represent the good quality reservoirs in this formation. With the integrated analysis of the porosity modeling, the acoustic inversion, and the evaluation of well logs, we concluded that the best reservoir facies are in the upper part of the Albian carbonate platform, corresponding to a high energy

\section{Structure in Time (ms)}

a)

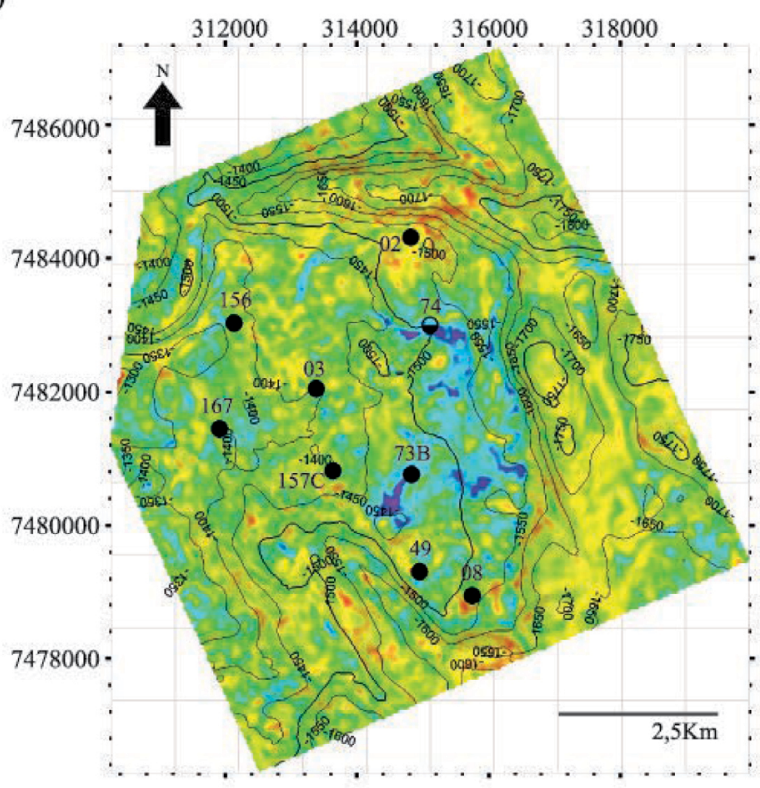

c)

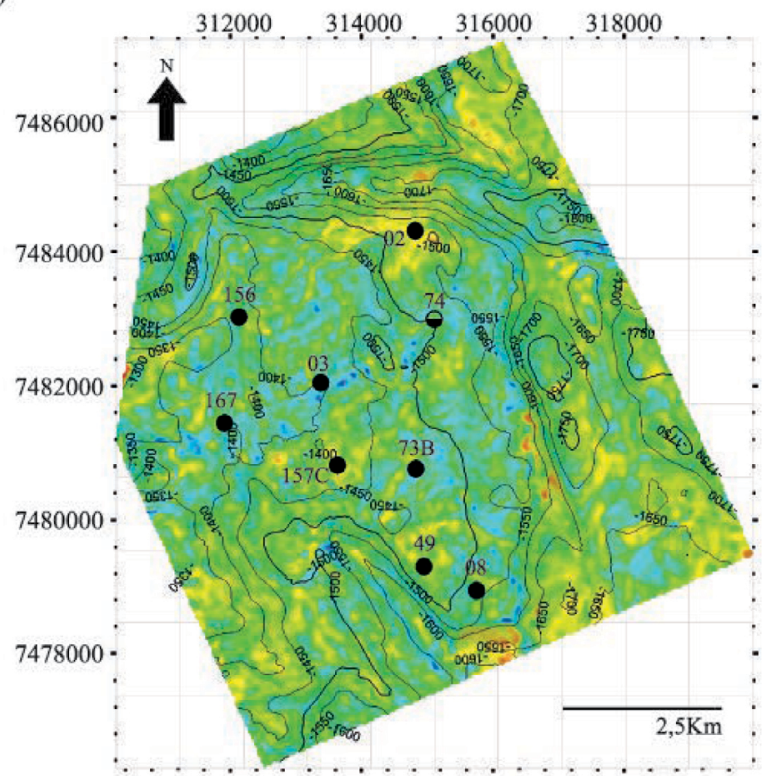

b)

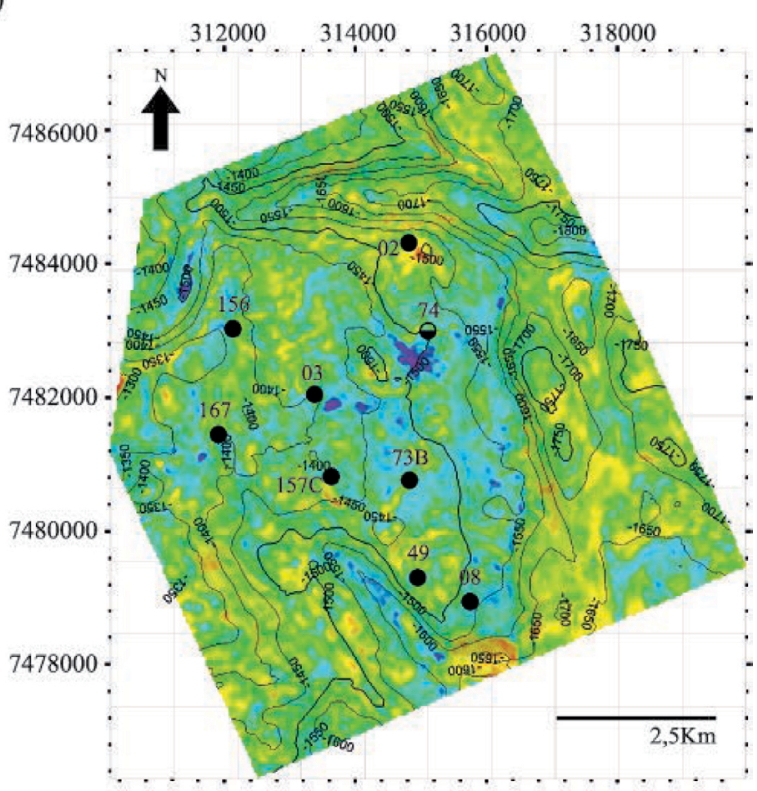

d)

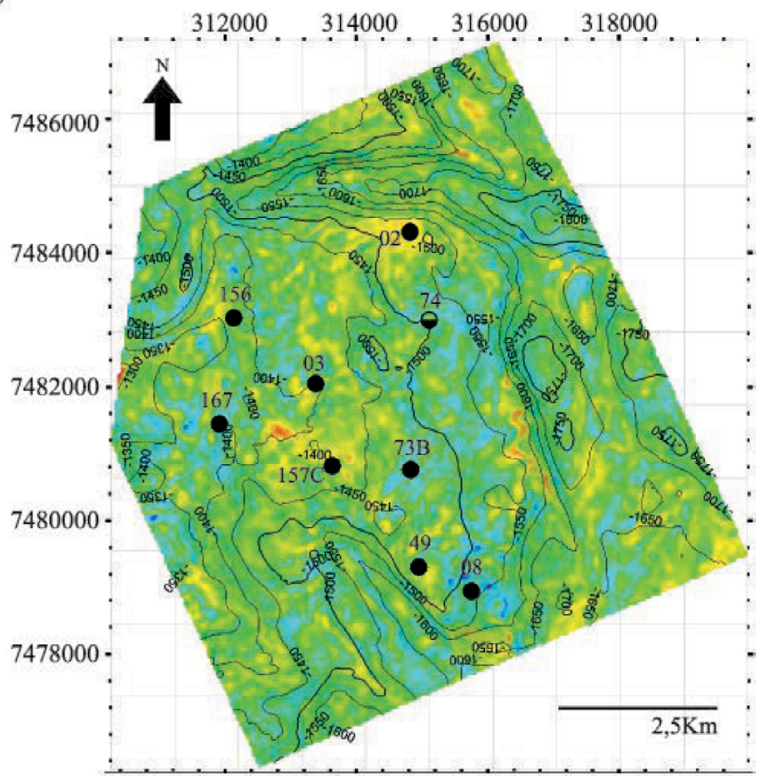

Acoustic Impedance $(\mathrm{m} / \mathrm{s})^{*}(\mathrm{~g} / \mathrm{cc})$

$6000 \quad 8225$

Figure 12. Acoustic impedance attribute map for the of the Quissamã Fm. surfaces with shifts of: (A) -12ms, (B) $-24 \mathrm{~ms}$, (C) $-36 \mathrm{~ms}$, and (D) $-48 \mathrm{~ms}$. Black circles represent the positions of the wells. In general, an increase in the acoustic impedance values at the well locations predominates with increasing depth. 

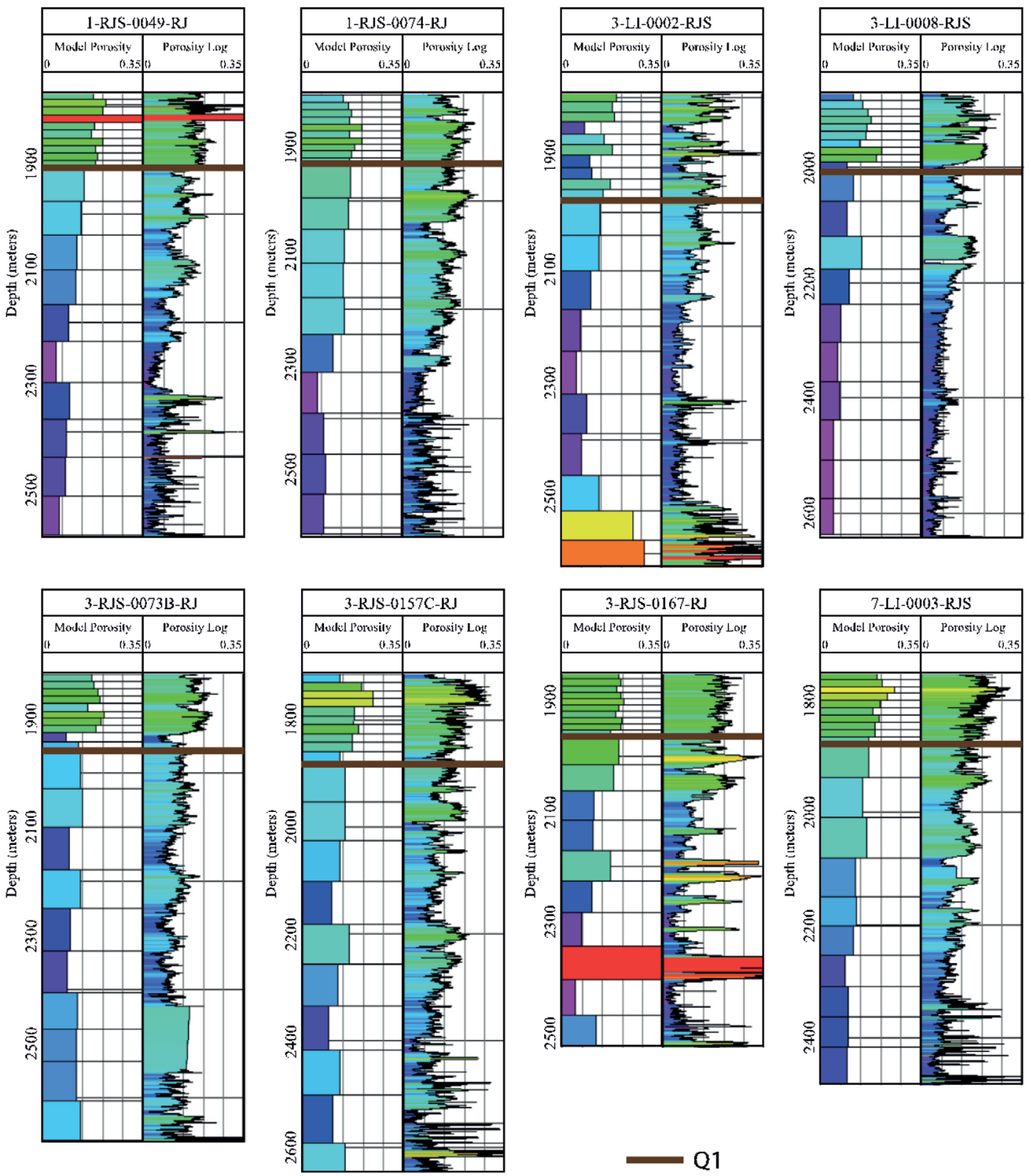

Figure 13. Porosity logs in seismic scale and the modeled porosities of wells.

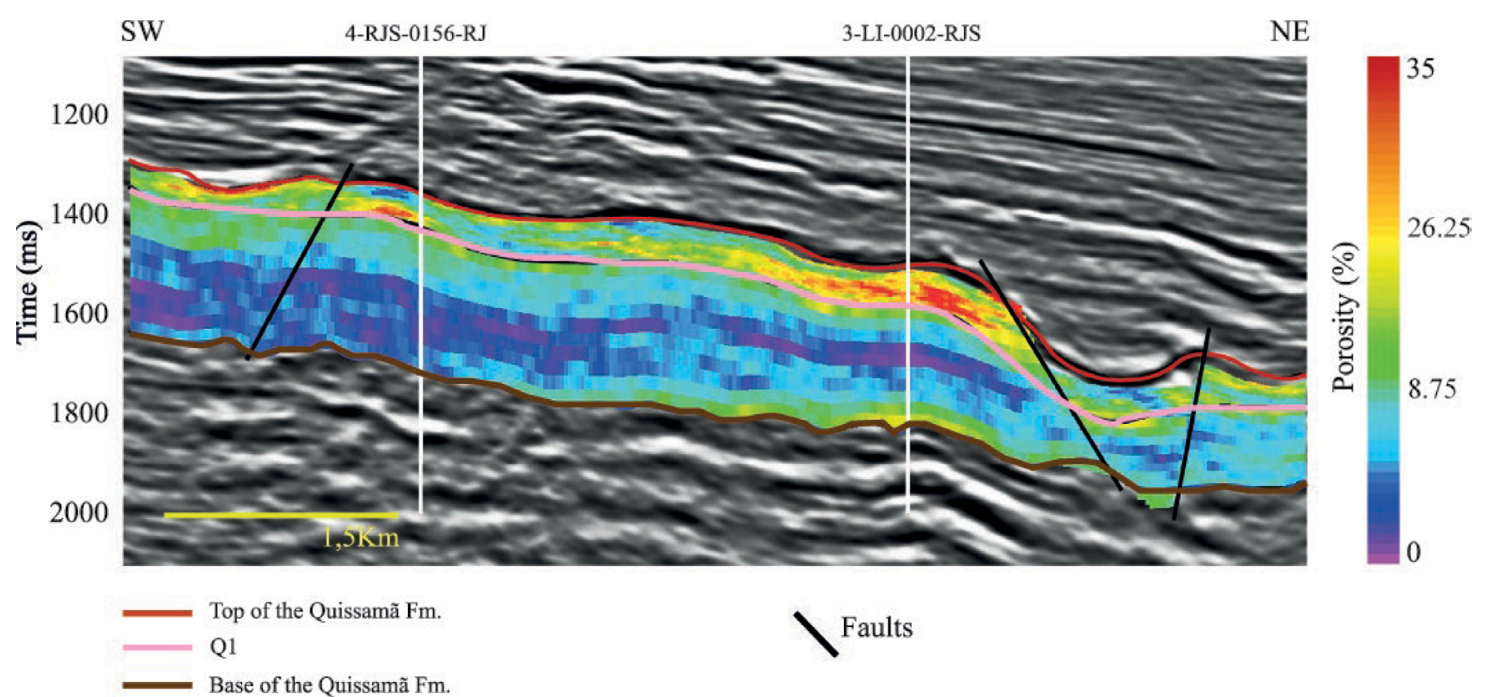

Figure 14. Porosity modeling for the inline 1607. The base of the Quissamã Fm., Q1 (intra-Albian) and the base of the Quissamã Fm. are represented by the brown, pink, and red lines, respectively. Faults are represented by the black lines. Porosity logs for the wells intersecting the section are shown for quality control. 


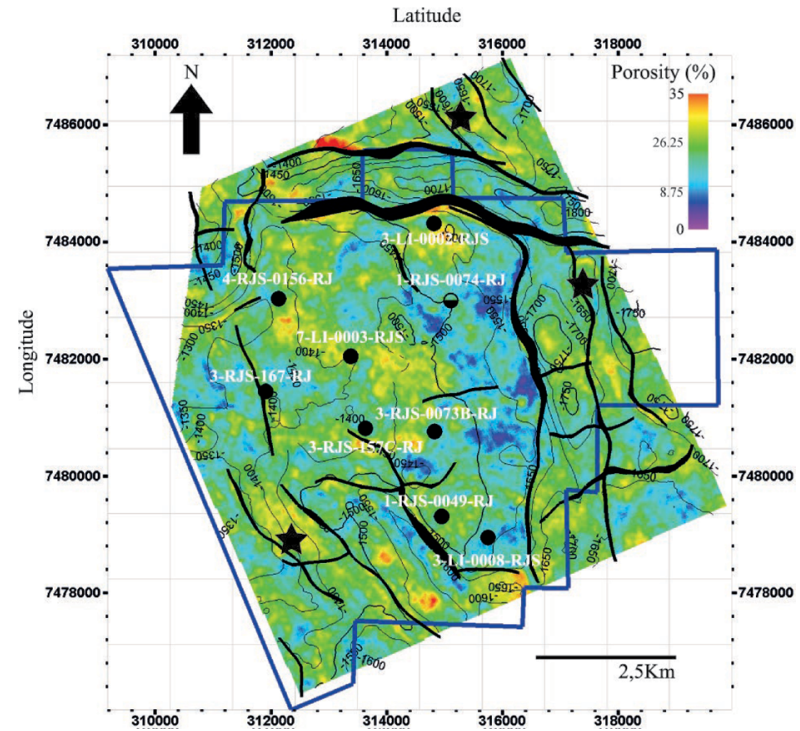

Figure 15. Porosity attribute map for the top of the Quissamã Fm. surface. Black circles represent the wells and black stars represent regions with high porosities that have not been drilled. Linguado Field study area is shown by the dark blue line.

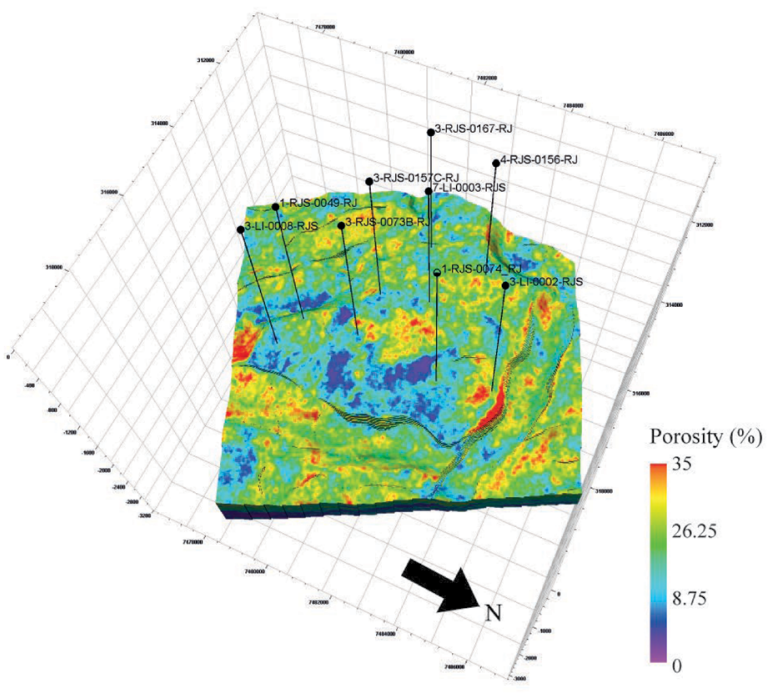

Figure 17. Porosity model represented in a 3D view.

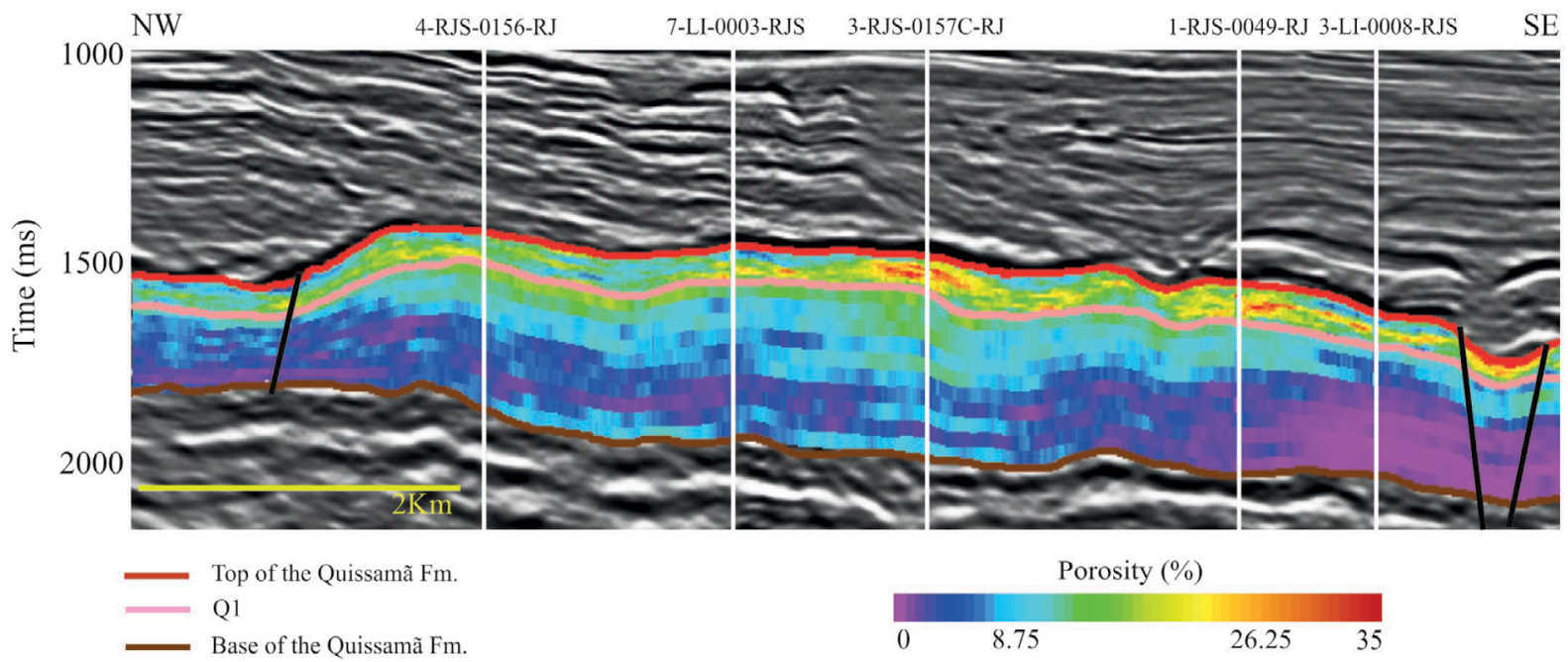

Figure 16. Amplitude seismic data and porosity modeled represented in $\mathrm{AB} 1$ line trace for comparison between the producing wells and the poor-producing well 1-RJS-0074-RJ.

zone. The area near well 1-RJS-0074-RJ presented high acoustic impedance and low porosity values, hence one of the possible reasons why it was classified as poor-producing. Finally, it was possible to identify regions with low acoustic impedance and high porosity values, that have not yet been drilled and which may represent a production enhancing of the field.

\section{ACKNOWLEDGMENTS}

The authors would like to thank the Agência Nacional do Petróleo, Gás Natural e Biocombustíveis (ANP) for providing the seismic data used in this research. They are also thankful to Schlumberger, for providing the Petrel Software, and to CGG, for providing the Hampson-Russell Software.

\section{ARTICLE INFORMATION}

Manuscript ID: 20190103. Received on: 10/06/2019. Approved on: 06/12/2020.

W.M.L. proposed the methodology, wrote the article, and carried out the formal analysis, review, supervision, and project administration. L.M.S.G. helped in the conceptualization and the writing of the manuscript. D.J.A.F. helped to write and revise the manuscript as well as to prepare the Figures. R.B. helped to revise the manuscript. A.F.M.F. helped to revise the manuscript and gave suggestions on the writing. Competing interests: The authors declare no competing interests. 


\section{REFERENCES}

Al-Rahim A.M., Hashem H.A. 2016. Subsurface 3D prediction porosity model from converted seismic and well data using model based inversion technique. Iraqi Journal of Science, 57(1A):163-174.

Azevedo L., Soares A. 2017. Geostatistical Methods for Reservoir Geophysics. Advances in Oil and Gas Exploration \& Production Series. Cham: Springer International Publishing, 159 p. http://doi. org/10.1007/978-3-319-53201-1

Azevedo R.L.M., Gomde I., Vivers M.C. 1987. Geo-histórla da Bacia de Campos, Brasil: do Albiano ao Maastrichtiano. Revista Brasileira de Geociências, 17(2):139-146.

Braga I.L.S., Moraes F.S. 2013. High-resolution gathers by inverse filtering in the wavelet domain. Geophysics, 78(2):V53-V61.

Bueno G.V. 2004. Diacronismo de eventos no rifte Sul Atlântico. Boletim de Geociências da Petrobras, 12(2):203-229.

Caers J. 2000. Adding local accuracy to direct sequential simulation. Mathematical Geology, 32(7):815-850. https://doi. org/10.1023/A:1007596423578

Candès E., Demanet L., Donoho D., Ying L. 2006. Fast discrete Curvelet Transforms. Multiscale Modeling \& Simulation, 5(3):861-899. https://doi. org/10.1137/05064182X

Dias-Brito D. 1987. A Bacia de Campos no Mesocretáceo: uma contribuição à paleoceanografia do Atlântico Sul Primitivo. Revista Brasileira de Geociências, 17(2):162-167.

Esteves F.R., Spadini A.R., Saito M. 1987. A sedimentação albo-turoniana (Formação Macaé) da Bacia de Campos 1o Simpósio de Geologia Regional. In: Simpósio de Geologia Regional RJ-ES, 1. Annals..., p. 27-42.

Favoreto J., Rohn R., Lykawka R., Okubo J. 2016. Caracterização sedimentológica dos carbonatos albianos do reservatório quissamã na porção meridional da bacia de campos. Geociências, 35(1):1-15.

Fernandes L., Vincentelli M.G.C., Perinotto J.A.J. 2017. Geological Settings and Seismic Attributes in Albian Carbonate Reservoirs - Southwest of Campos Basin (RJ - Brazil). Revista Brasileira de Geofísica, 35(2):109-121. http://dx.doi.org/10.22564/rbgf.v35i2.808

Ferreira D.J.A., Lupinacci W.M. 2018. An approach for three-dimensional quantitative carbonate reservoir characterization in the Pampo field, Campos Basin, offshore Brazil. AAPG Bulletin, 102(11):2267-2282. https://doi.org/10.1306/04121817352

Franke R. 1982. Scattered data interpolation: tests of some methods. Mathematics of Computation, 38(157):181-200. http://dx.doi. org/10.2307/2007474

Guardado L., Gamboa L.A.P., Lucchesi C.F. 1989. Petroleum geology of the Campos Basin, Brazil, a model for a producing Atlantic Type Basin. AAPG Memoir, (A132):3-36. https://doi.org/10.1306/M48508C1

Jalalalhosseini S.M., Eskandari S., Mortezazadeh E. 2015. The technique of seismic inversion and use of the relation between inversion results and porosity log for predicting porosity of a carbonate reservoir in a south Iranian oil field. Energy Sources, Part A: Recovery, Utilization and Environmental Effects, 37(3):265-272. https://doi.org/10.1080/15567036.2011.580326

Jarvis K. 2006. Integrating well and seismic data for reservoir characterization: risks and rewards. ASEG Extended Abstracts, 2006(1):1-4. https://doi. org/10.1071/ASEG2006ab074

Karin S.U., Islam M.S., Hossain M.M., Islam M.A. 2016. Seismic reservoir characterization using model based post-stack seismic inversion: in case of Fenchuganj Gas Field, Bangladesh. Journal of the Japan Petroleum Institute, 59(6):283-292. https://doi.org/10.1627/jpi.59.283

Lupinacci W.M., Franco A.P., Oliveira S.A.M., Moraes F.S. 2017. A combined time-frequency filtering strategy for Q-factor compensation of poststack seismic data. Geophysics, 82(1):V1-V6. https://doi.org/10.1190/ geo2015-0470.1

Marçal R.A. 1993. Caracterização das feições diagenéticas de fatores controladores da diagênese em rochas carbonáticas albianas da margem continental brasileira. Dissertation, Universidade Federal de Ouro Preto, Ouro Preto.

Maurya S.P., Singh K.H. 2015. Reservoir characterization using model based inversion and probabilistic neural network. Discovery, 49(228):122-127.

Okubo J., Lykawka R., Warren L.V., Favoreto J., Dias-Brito D. 2015. Depositional, diagenetic and stratigraphic aspects of Macaé Group carbonates (Albian): example from an oilfield from Campos Basin. Brazilian Journal of Geology, 45(2):243-258. http://dx.doi.org/10.1590/231748892 01500020005

Pramudito D., Meidiana T., Alfianto A.D., Nurhadi D.R., 2017. How to build new interpretation concept using dynamic data: A case study in carbonate of Upper Cibulakan, North West Java Basin, Indonesia. IOP Conference Series: Earth and Environmental Science, 62:1-7.

Russell B., Hampson D. 1991. Comparison of poststack seismic inversion methods. SEG Technical Program Expanded Abstracts, 10(1):876-878. http://dx.doi.org/10.1190/1.1888870

Russell B.H., Hampson D. 2006. The old and the new in seismic inversion. Canadian Society of Exploration Geophysicists Recorder, 31(10):5-11.

Spadini A.R., Esteves F.R., Dias-Brito D., Azevedo R.L.M., Rodrigues R. 1988. The Macae Formation, Campos Basin, Brazil: its evolution in the context of the initial history of the South Atlantic. Revista Brasileira de Geociências, 18(3):261-272.

Spadini A.R., Paumer M.L. 1983. Os reservatórios Macaé no Campo de Pampo: o meio poroso e a diagenese. Rio de Janeiro: Petrobras (Internal report).

Winter W.R., Jahnert R.J., França A.B. 2007. Bacia de Campos. Boletim de Geociências da Petrobras, 15(2):511-529.

Yamamoto J.K., Landim P.M.B. 2013. Geoestatística: conceitos e aplicações. $1^{\text {a }}$ ed. São Paulo: Oficina de Textos. 